\title{
Results of Long-Term Experimental Studies on the Carcinogenicity of Methyl Alcohol and Ethyl Alcohol in Rats
}

\author{
MORANDO SOFFRITTI, FIORELLA BELPOGGI, DANIELA CEVOLANI, \\ MARINA GUARINO, MICHELA PADOVANI, AND CESARE MALTONI ${ }^{\dagger}$ \\ Cancer Research Center, European Ramazzini Foundation for Oncology and \\ Environmental Sciences, Bologna, Italy
}

\begin{abstract}
Methyl alcohol was administered in drinking water supplied ad libitum at doses of $20,000,5,000,500$, or $0 \mathrm{ppm}$ to groups of male and female Sprague-Dawley rats 8 weeks old at the start of the experiment. Animals were kept under observation until spontaneous death. Ethyl alcohol was administered by ingestion in drinking water at a concentration of $10 \%$ or $0 \%$ supplied ad libitum to groups of male and female Sprague-Dawley rats; breeders and offspring were included in the experiment. Treatment started at 39 weeks of age (breeders), 7 days before mating, or from embryo life (offspring) and lasted until their spontaneous death. Under tested experimental conditions, methyl alcohol and ethyl alcohol were demonstrated to be carcinogenic for various organs and tissues. They must also be considered multipotential carcinogenic agents. In addition to causing other tumors, ethyl alcohol induced malignant tumors of the oral cavity, tongue, and lips. These sites have been shown to be target organs in man by epidemiologic studies.
\end{abstract}

KEYWORDS: methyl alcohol; ethyl alcohol; carcinogenicity; long-term bioassay; rat

\section{INTRODUCTION}

Automobiles and gasoline are two of the main consumer products characterizing the modern age. The annual consumption of gasoline has been estimated at over $600,000,000$ tons throughout the world. With its vapors and combustion products, gasoline contributes in a decisive way to polluting the biosphere. The gasoline-car combination has turned progressively into an ecological and health problem, affecting the physical, chemical, and biological equilibria of the earth's biosphere, likely with a parallel effect on the health of man. Our awareness of the size and urgency of the ecological and health hazard calls for the promotion of strategies to deal with the problem.

Address for correspondence: Morando Soffritti, M.D., Cancer Research Center, European Ramazzini Foundation for Oncology and Environmental Sciences, Bentivoglio Castle, 40010 Bentivoglio (BO), Italy. Voice: +39-051-6640460; fax: +39-051-6640223.

crcfr@tin.it

†Deceased.

Ann. N.Y. Acad. Sci. 982: 46-69 (2002). () 2002 New York Academy of Sciences. 
Technological improvements may include: (1) producing less polluting gasolines in terms of both vapors and compounds generated by combustion; (2) designing engines geared to a lower emission of combustion products; and (3) producing systems for containing combustion products (such as catalytic converters). Producing less polluting gasolines calls for biomedical research aimed at identifying the potential toxic and carcinogenic effects of various kinds of gasoline, their components and combustion products, gauging what point such effects have currently reached, and producing a comparative evaluation of the risks. While the introduction of new fuels and gasoline additives may decrease certain components that are toxic to health and to the environment, it may generate new ones. No new fuel should be introduced as an improvement until research has proven it safe.

In 1975, the laboratory of the Cancer Research Center of the Ramazzini Foundation (CRC/RF) started a systematic project of carcinogenicity bioassays on: (1) various types of gasolines and other petroleum-derived fuels, namely, European unleaded gasoline (with a high content of aromatics), unleaded reformulated gasoline, leaded gasoline, gasoline containing 3\% methyl alcohol, gasoline containing $5 \%$ ethyl alcohol, gasoline containing $15 \%$ methyl tert-butyl ether (MTBE), gasoline containing $15 \%$ ethyl tert-butyl ether (ETBE), kerosene, diesel fuel, and naphtha; (2) some of the major aromatic components such as benzene, toluene, xylenes, ethylbenzene, and 1,2,4-trimethylbenzene; (3) various types of octane enhancers such as the oxygenated additives methyl alcohol, ethyl alcohol, MTBE, ETBE, tertiary-amyl-methyl ether (TAME), di-isopropyl ether (DIPE), and the isoparaffin 2,2,4-trimethylpentane (TMP); (4) automobile exhaust and combustion products of note in oxygenated additive-containing gasolines such as formaldehyde and acetaldehyde; and (5) catalysts such as artificial zeolites and precursors used in petroleum refining.

For the CRC/RF project on fuels, 51 carcinogenicity bioassays have been performed, 42 industrial products studied, and more than 20,000 experimental animals used. This project is, to our knowledge, unique. The results of the experiments on European unleaded gasoline with a high content of aromatics, ${ }^{1}$ leaded gasoline, ${ }^{1}$ kerosene, ${ }^{1}$ diesel fuel,${ }^{1}$ benzene,${ }^{2}$ toluene, ${ }^{1}$ xylenes, ${ }^{1}$ ethylbenzene, ${ }^{1} 1,2,4$-trimethyl benzene, ${ }^{1}$ MTBE, ${ }^{3}$ ETBE, ${ }^{4}$ and preliminary results on formaldehyde ${ }^{5}$ have been published. This report outlines the final results of the carcinogenicity experiments performed at the CRC/RF on methyl alcohol and ethyl alcohol, two compounds proposed as oxygenated additives/alternative fuels.

Methyl alcohol is a clear, colorless, volatile, flammable liquid with a mild alcoholic odor. It is miscible with water and many organic solvents and forms many binary and zeotropic mixtures. ${ }^{6}$ Methyl alcohol $\left(\mathrm{CH}_{3} \mathrm{OH}\right)$ has a molecular weight of 32.04. Most methyl alcohol is produced by catalytic conversion of pressurized synthesis gas (hydrogen, carbon monoxide, and carbon dioxide) in the presence of metallic heterogeneous catalysts. ${ }^{7,8}$ Since 1979 , the world production of methyl alcohol has steadily increased and is now greater than 30 million tons per year. ${ }^{9}$

Approximately $70 \%$ of the methyl alcohol produced worldwide is used as feedstock and for the chemical synthesis of formaldehyde, MTBE, acetic acid, methyl metacrylate, and dimethyl terphtalate. ${ }^{6}$ Methyl alcohol is a potential substitute for petroleum. It can be directly used in fuels as a replacement for gasoline and as an additive in gasoline and diesel fuel. Methyl alcohol is favored over conventional fuels because of its lower ozone-forming potential, lower emission of some pollut- 
ants, particularly benzene, polycyclic aromatic hydrocarbons, and sulfur compounds, and its low evaporative emissions. On the other hand, the possibility of higher formaldehyde emissions, its higher acute toxicity, and, at present, lower costefficiency favor conventional fuels. ${ }^{10}$ Methyl alcohol is not usually used alone but is included in solvent mixtures. ${ }^{11}$

Methyl alcohol occurs naturally in humans, animals, and plants. ${ }^{12-20}$ Natural emission sources of methyl alcohol include volcanic gasses, vegetation, microbes, and insects. ${ }^{21-23}$ In 1994, the U.S. EPA reported that methyl alcohol was the most released chemical to the environment. ${ }^{24}$

Urban air levels of methyl alcohol of $10.5-131 \mu \mathrm{g} / \mathrm{m}^{3}(8-100 \mathrm{ppb})$ have been reported. ${ }^{23}$ If methyl alcohol, either $100 \%$ or in gasoline blends, becomes a major automotive fuel, emissions of methyl alcohol may arise as uncombusted fuel in exhaust or from evaporation during refueling. ${ }^{25}$ Some methyl alcohol exposure concentrations have been postulated for various scenarios. For instance, in a public garage, if $100 \%$ of vehicles were fueled with methyl alcohol, air concentrations were projected to be $150 \mathrm{ppm}$. In most cases, exposure of the general public would be brief but repeated over time. ${ }^{26}$

Data on the occurrence of methyl alcohol in water, particularly drinking water, are limited. Methyl alcohol was identified in water in 24 locations in the United States during the period 1974-1976. ${ }^{27}$ The frequency of occurrence was as follows: finished drinking water, 12; effluents from chemical plants, 6; effluent from sewage treatment, 4; effluent from paper and latex production, 1.

Dietary methyl alcohol can arise in large part from fresh fruit and vegetables. The methyl alcohol content of fresh and canned fruit juices, principally orange and grapefruit juices, varies considerably and may range from $1-43 \mathrm{mg} / \mathrm{L}$ to $12-640 \mathrm{mg} / \mathrm{L}$, with an average of $140 \mathrm{mg} / \mathrm{L} .{ }^{28-30}$ Fermented and distilled beverages can contain high levels of methyl alcohol. ${ }^{31}$ The sweetening agent aspartame hydrolyzes in the gastrointestinal tract to become free methyl alcohol. ${ }^{25}$

The primary routes of methyl alcohol exposure are inhalation and ingestion. Methyl alcohol distributes readily and uniformly in tissues in direct relation to their water content. In all mammalian species studied, methyl alcohol is metabolized in the liver by sequential oxidative steps to formaldehyde, formic acid, and $\mathrm{CO}_{2} \cdot{ }^{6}$ However, there are wide differences in the route of formate oxidation among different species that determine the sensitivity to methyl alcohol ${ }^{6}$ Oral administration to rats showed an $\mathrm{LD}_{50}$ in the range of $7.4-13 \mathrm{~g} / \mathrm{kg} \mathrm{bw} .^{32}$

In vitro and in vivo mutagenicity studies on methyl alcohol, such as the Ames test, somatic mutation assay in $\mathrm{CH}-\mathrm{V} 79$ cells, chromosome aberrations, sister chromatide exchanges, and the micronucleus test in mice, were all reported to be negative. ${ }^{33,34}$ There are no reports of genotoxic, reproductive, or developmental effects in humans from methyl alcohol exposure. ${ }^{6}$

Although more than 30 million tons per year of methyl alcohol are produced, carcinogenicity studies are less than adequate. In two carcinogenicity studies, performed by the New Energy Development Organization (NEDO) in Japan, in which B6C3 $\mathrm{F}_{1}$ mice and Fisher 344 rats of both sexes were exposed by inhalation to 10 , 100 , and 1,000 ppm methyl alcohol for 20 hours/day for 18 and 24 months, respectively, no evidence of carcinogenicity was found in either species. ${ }^{33,} 34$

In a pilot study performed at the $\mathrm{CRC} / \mathrm{RF}$, Sprague-Dawley rats were exposed to 15 or 0 ppm methyl alcohol administered in drinking water for 104 weeks and then 
observed until spontaneous death. An increase in the incidence of total malignant tumors and leukemia (mostly in males) was observed. ${ }^{5}$ The final results of this study are reported in this volume in the report on formaldehyde.

Ethyl alcohol $\left(\mathrm{CH}_{3} \mathrm{CH}_{2} \mathrm{OH}\right)$ has a molecular weight of 46.07. Ethyl alcohol may be produced from fermentation and petroleum ethylene synthesis. ${ }^{35}$ Ethyl alcohol is one of the most widely produced, used, and diffused compounds at the global level.

The ethyl alcohol contained in alcoholic beverages (wine, beer, spirits, etc.), amounted to an annual world production in the mid-1980s of over 110 million hectoliters. ${ }^{36}$ The total fuel ethyl alcohol production worldwide was around 200 million hectoliters in 2001. If all recently announced ethyl alcohol projects are implemented, the total worldwide ethyl alcohol fuel production could grow to 310 million hectoliters by $2006 .{ }^{37}$

Ethyl alcohol is used in many industrial processes, namely, the pharmaceutical, cosmetic, and synthetic rubber industries, as an antifreeze and as a solvent or processing agent for various purposes. ${ }^{38}$ Ethyl alcohol is naturally present in alcoholic beverages as a consequence of fermentation of carbohydrates with yeast. ${ }^{39}$

Ethyl alcohol is proposed as a fuel, as an oxygenated additive of gasoline, and as a precursor of ETBE, a synthetic additive of gasoline, an alternative to/competing with the oxygenated additive most commonly used today, MTBE. The possibility that ethyl alcohol may be widely used as a fuel, as an oxygenated additive of gasoline, or in the production of ETBE increases the risk of its diffusion in surface and groundwater during production, storage, transportation, and use, as from the emission of exhaust from vehicles as an unburned product of gasoline combustion. The combustion of ethyl alcohol and its metabolic transformation in the body produce acetaldehyde which, according to data in the literature and the results of experiments conducted at $\mathrm{CRC} / \mathrm{RF}$ reported in this volume, has a carcinogenic potential in laboratory animals.

Data on the air concentration of ethyl alcohol are few. The average ambient level in air in the city of Porto Alegre, Brazil, where vehicles run entirely on ethyl alcohol, is $0.023 \mathrm{mg} / \mathrm{m}^{3}$ (12 ppb). ${ }^{40}$ Atmospheric degradation is predicted to be rapid. ${ }^{41}$ Ethyl alcohol rapidly degrades in groundwater and is not expected to persist beyond source areas. Ethyl alcohol in surface water is expected to undergo rapid biodegradation as long as it is not present in concentrations directly toxic to microorganisms. $^{41,42}$ Ethyl alcohol is not likely to accumulate or persist long in the environment. ${ }^{39}$

Although a great deal of information on the toxicological and health effects of ingested ethyl alcohol as a beverage is available, relatively little is known about its effects by inhalation exposure, which is relevant to its use as a fuel. About $60 \%$ of inhaled ethyl alcohol is retained by the body; the gastrointestinal tract completely absorbs ethyl alcohol in 2 to 6 hours; dermal absorption is insignificant. ${ }^{43,44}$ From the portals of entry, ethyl alcohol distributes fairly uniformly throughout all tissues and organs, including the cerebrospinal fluid, brain, and, in pregnant human and laboratory animals, placenta and fetal tissues. ${ }^{43,44}$ Ethyl alcohol is metabolized to acetaldehyde, which is then metabolized to $\mathrm{CO}_{2}$ and water. ${ }^{45}$

Many epidemiologic studies have shown a positive relation between alcohol intake and excess tumors of the oral cavity, pharynx, larynx, esophagus, and liver. ${ }^{46}$ These studies, however, do not show the total carcinogenic potential of ethyl alcohol. Ethyl alcohol has been the subject of 18 experimental studies on rodents, all of 
them considered less than adequate for the evaluation of carcinogenic potential. ${ }^{46}$ Ethyl alcohol, given in association with nitrosamine or vinyl chloride, increases the carcinogenic potential of these compounds. ${ }^{46}$ Because of the expansion in the use and diffusion of ethyl alcohol in the workplace and environment and the lack of adequate experimental data to evaluate its carcinogenicity, experiments on ethyl alcohol described herein were performed.

\section{MATERIALS AND METHODS}

Methyl alcohol is produced by J.T. Baker, Deventer, Holland, and has a purity grade of $99.8 \%$. Ethyl alcohol was supplied by "CARLO ERBA" pharmaceutical products, Milan, Italy, in 1-liter glass bottles every 3 months; its purity was higher than $99.8 \%$. The impurities were the following: acidity (acetic acid) $\leq 0.001 \%$; alkalinity $\left(\mathrm{NH}_{3}\right)$ $\leq 0.0001 \%$; carbonyl compound $(\mathrm{CO}) \leq 0.0005 \%$; isopropyl alcohol $\leq 0.003 \%$; methanol $\left(\mathrm{CH}_{3} \mathrm{OH}\right) \leq 0.01 \%$; residue on evaporation $\leq 0.001 \% ; \mathrm{H}_{2} \mathrm{O} \leq 0.2 \%$.

During the experiment, both compounds were stored at a temperature of $4{ }^{\circ} \mathrm{C}$. Methyl alcohol was administered in drinking water at concentrations of 20,000, 5000,500 , or 0 ppm supplied ad libitum for 104 weeks to groups of male and female Sprague-Dawley rats beginning at 8 weeks of age. Control animals received tap water. The experiment on methyl alcohol started in April 1990 and ended after 153 weeks with the death of the last animal at 161 weeks of age.

Ethyl alcohol was administered in drinking water at concentrations of $10 \%$ or $0 \%$ supplied ad libitum to groups of male and female Sprague-Dawley rats; breeders and offspring were included in the experiment. Treatment started at 39 weeks of age (breeders), 7 days before mating, or from embryo life (offspring) and lasted until their spontaneous death. Control animals received tap water. The experiment on ethyl alcohol started in January 1986 and ended with the death of the last offspring at 179 weeks of age. Experiments were performed according to Good Laboratory Practices (GLP) and Standard Operating Procedure (SOP) of the CRC/RF.

Animals were identified by ear punch and housed in groups of five in makrolon cages $(41 \times 25 \times 15 \mathrm{~cm})$ with a stainless steel wire top; a shallow layer of white wood shavings served as bedding. The animals were kept in a single room at $23 \pm 2{ }^{\circ} \mathrm{C}$ and $50-60 \%$ relative humidity.

Each morning, residual liquids from the previous day were removed, and the glass drinking bottles were washed and filled with fresh solution. Mean daily drinking water and feed consumption and weight were determined once weekly for the first 13 weeks and then every 2 weeks for 104 weeks. Thereafter, animals were weighed every 8 weeks until the end of the experiment. Status and behavior of animals were examined 3 times daily, and they were submitted to clinical examination for gross changes every 2 weeks.

Upon death, animals underwent systematic necropsy. Histopathology was routinely performed on the following organs and tissues: skin and subcutaneous tissue, brain, pituitary gland, Zymbal glands, parotid glands, submaxillary glands, Harderian glands, cranium (with oral and nasal cavities and external and internal ear ducts) (5 sections of head), tongue, thyroid and parathyroid, pharynx, larynx, thymus and mediastinal lymph nodes, trachea, lung and mainstem bronchi, heart, diaphragm, liver, spleen, pancreas, kidneys, adrenal glands, esophagus, stomach (fore and glan- 
TABLE 1. Long-term carcinogenicity bioassays on methyl alcohol administered with drinking water supplied ad libitum to male (M) and female (F) Sprague-Dawlwy rats

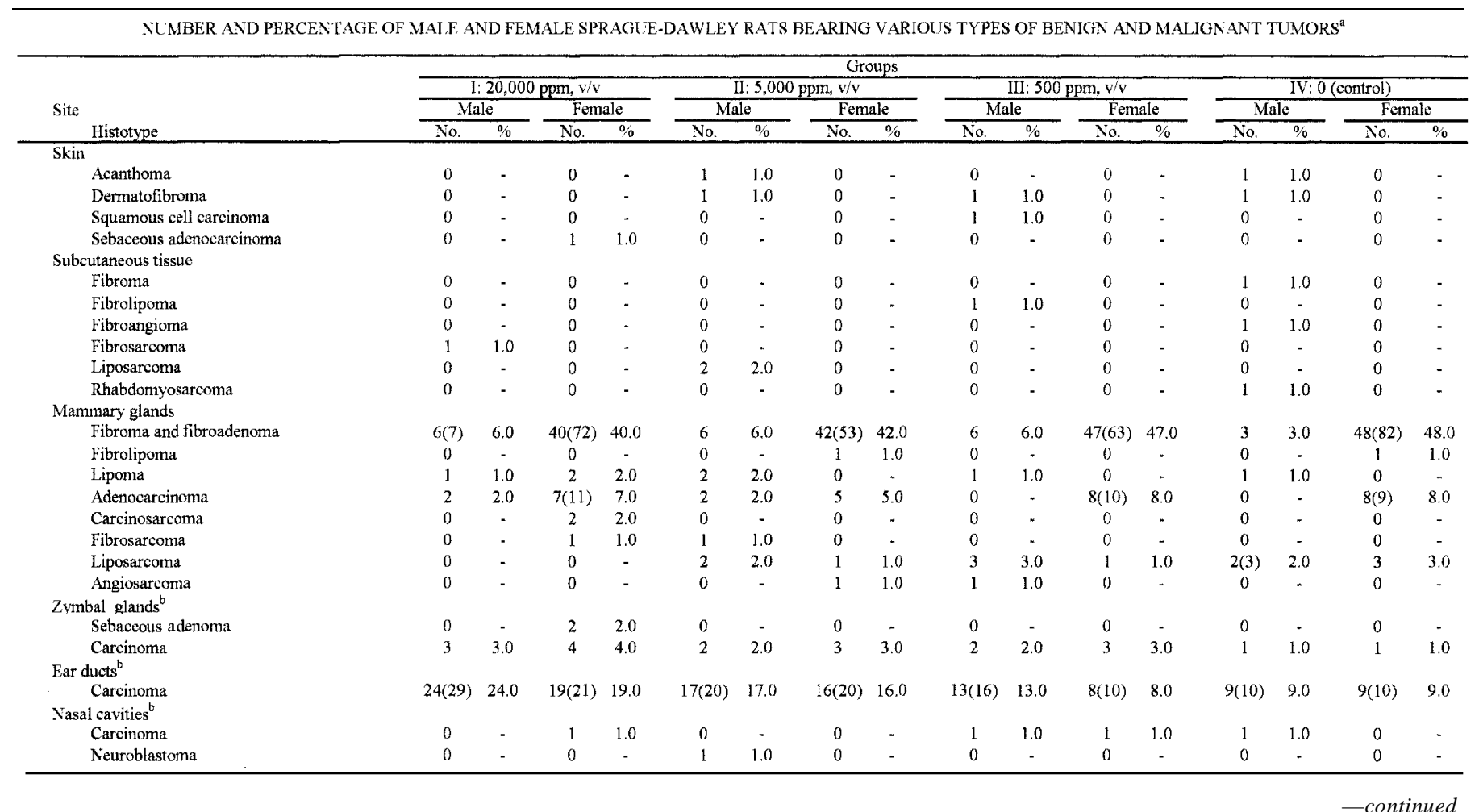




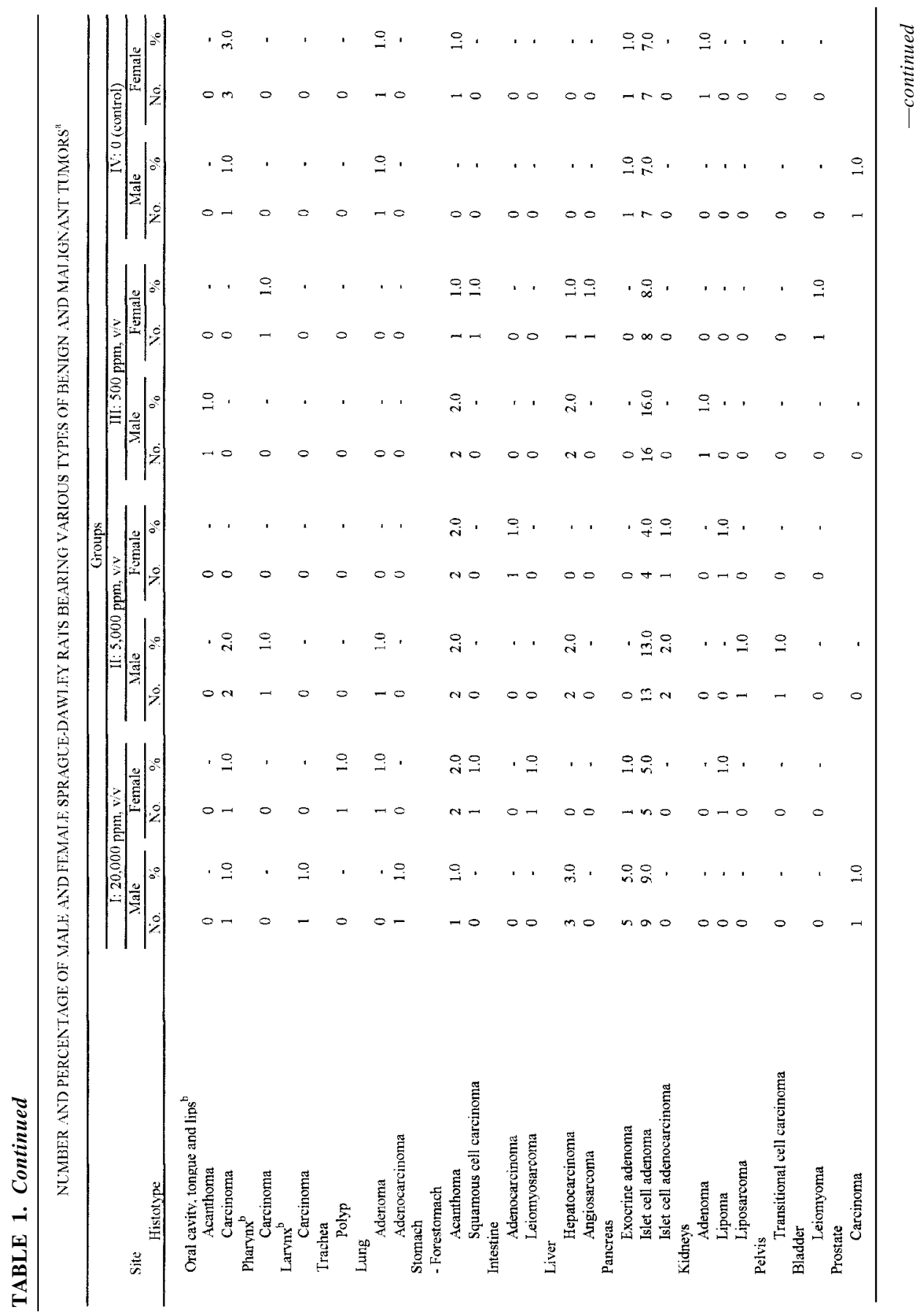




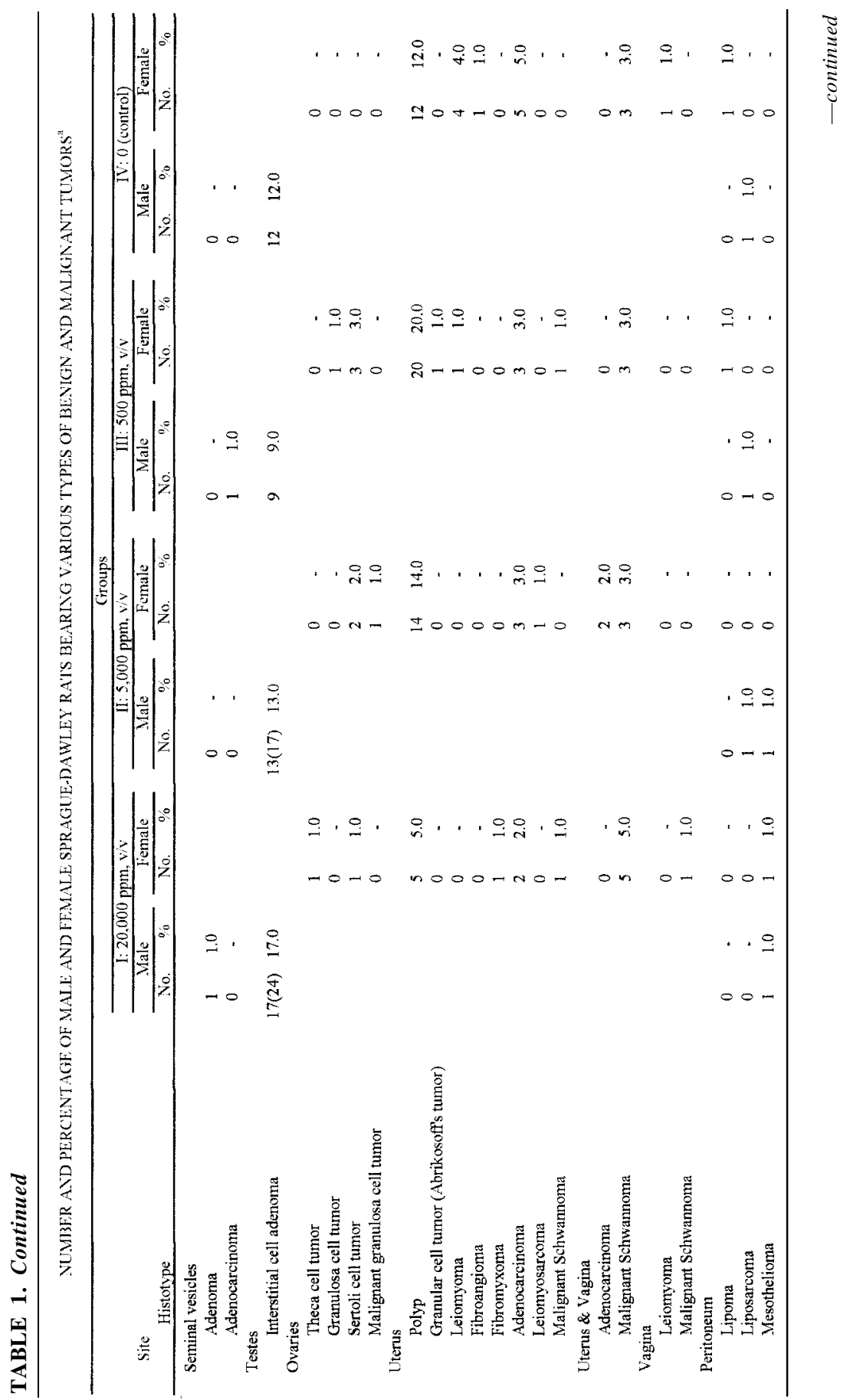




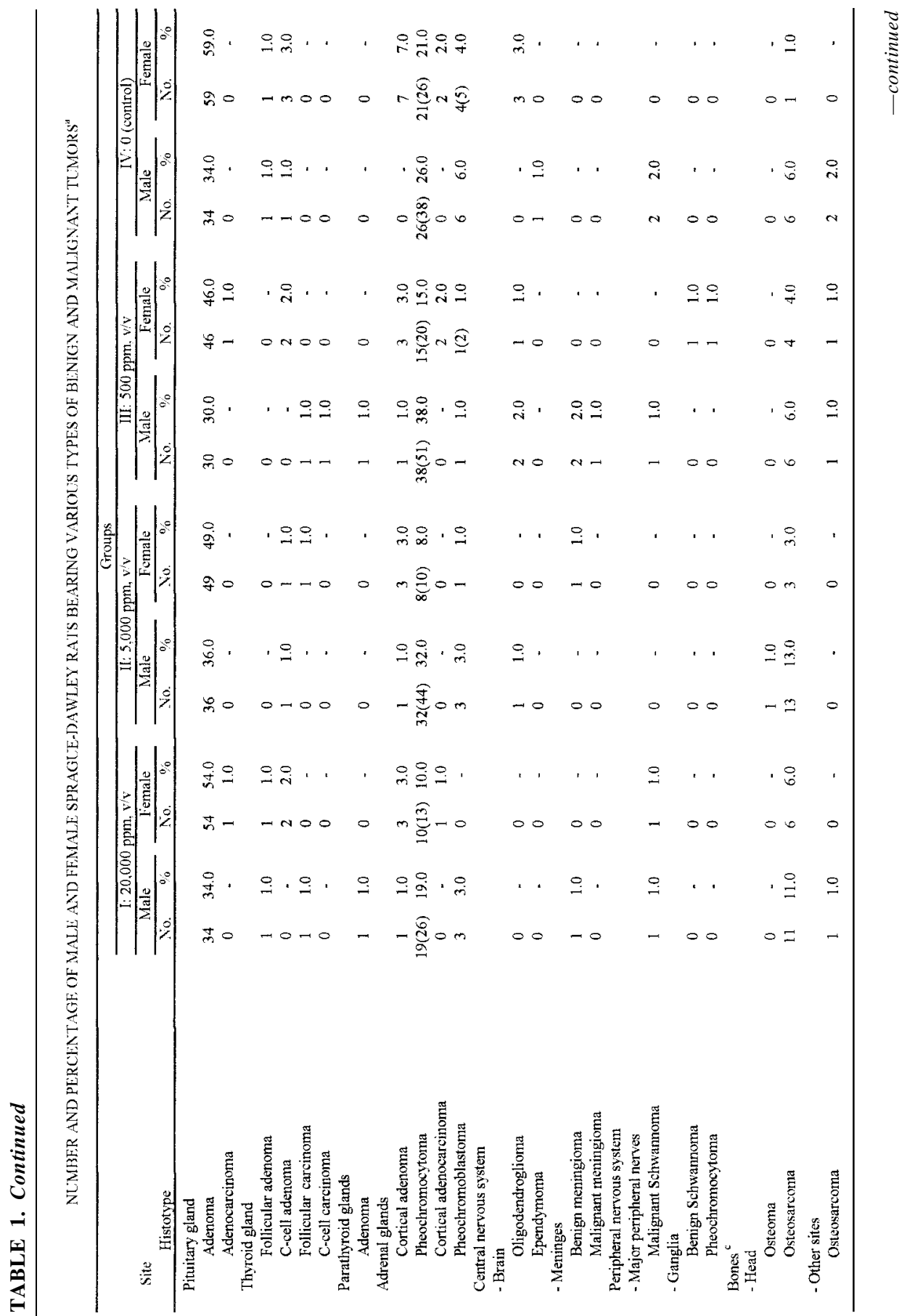




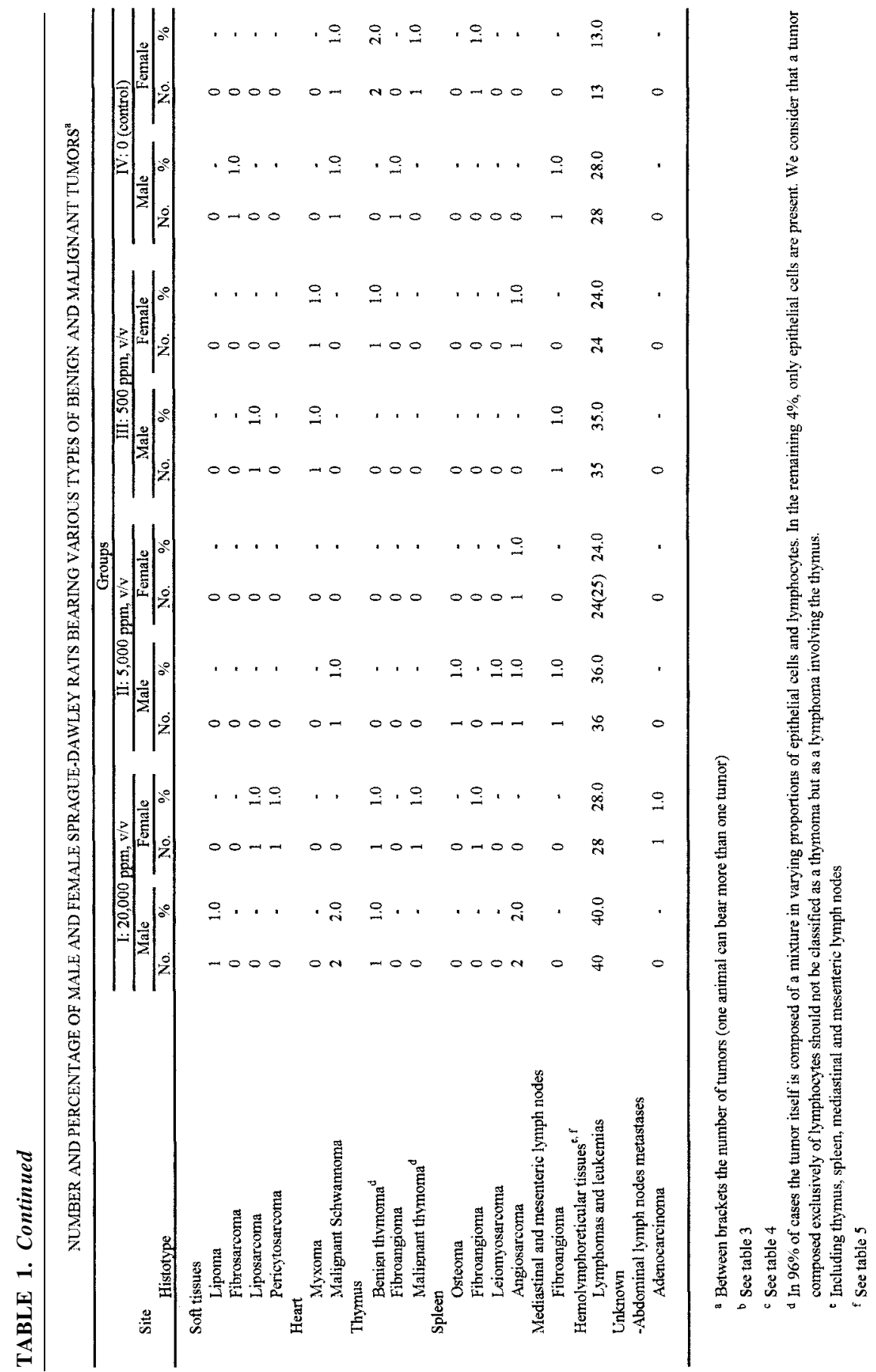


TABLE 2. Long-term carcinogenicity bioassays on methyl alcohol administered with drinking water supplied ad libitum to male (M) and female (F) Sprague-Dawley rats

TO'TAL MALIGNANT TUMORS

\begin{tabular}{|c|c|c|c|c|c|c|c|}
\hline \multirow{3}{*}{$\begin{array}{c}\text { Group } \\
\text { No. }\end{array}$} & \multirow{3}{*}{$\begin{array}{l}\text { Concentration } \\
(\mathrm{ppm}, \mathrm{v} / \mathrm{v})\end{array}$} & \multirow{2}{*}{\multicolumn{2}{|c|}{ Animals }} & \multicolumn{4}{|c|}{ Malignant tumors } \\
\hline & & & & \multicolumn{2}{|c|}{ Tumor-bearing animals } & \multicolumn{2}{|c|}{ Tumors } \\
\hline & & Sex & No. & No. & $\%$ & No. & Per 100 animals \\
\hline \multirow[t]{3}{*}{ I } & 20,000 & $\mathrm{M}$ & 100 & 70 & $70.0^{-m+4}$ & 104 & $104.0^{+*}$ \\
\hline & & $\mathrm{F}$ & 100 & 63 & $63.0^{\cdots+* 4}$ & 95 & $95.0^{+4}$ \\
\hline & & $\mathrm{M}+\mathrm{F}$ & 200 & 133 & 66.5 & 199 & 99.5 \\
\hline \multirow[t]{3}{*}{ II } & 5,000 & $\mathrm{M}$ & 100 & 64 & $64.0^{+4}$ & 97 & $97.0^{4+\infty}$ \\
\hline & & $\mathrm{F}$ & 100 & 48 & $48.0^{\circ}$ & 73 & 73.0 \\
\hline & & $\mathrm{M}+\mathrm{F}$ & 200 & 112 & 56.0 & 170 & 85.0 \\
\hline \multirow[t]{3}{*}{ III } & 500 & $\mathrm{M}$ & 100 & 55 & 55.0 "* & 78 & $\mathbf{7 8 . 0}$ \\
\hline & & $\mathrm{F}$ & 100 & 48 & $48.0^{*}$ & 72 & 72.0 \\
\hline & & $\mathrm{M}+\mathrm{F}$ & 200 & 103 & 51.5 & 150 & 75.0 \\
\hline \multirow[t]{3}{*}{ IV } & 0 & $\mathrm{M}$ & 100 & 50 & 50.0 & 66 & 66.0 \\
\hline & & $\mathrm{F}$ & 100 & 43 & 43.0 & 60 & 60.0 \\
\hline & & $\mathrm{M}+\mathrm{F}$ & 200 & 93 & 46.5 & 126 & 63.0 \\
\hline
\end{tabular}

$p<0.01$ using $\chi^{2}$ test

*t $\mathrm{p}<0.01$ using Cochrane-Armitage test for dose-response relationship

dular), intestine (four levels), urinary bladder, prostate, gonads, interscapular fat pad, subcutaneous and mesenteric lymph nodes, and any other organs or tissues with pathologic lesions. All slides were examined microscopically by the same group of pathologists; a senior pathologist reviewed all tumors and any other lesion of oncologic interest. All pathologists followed the same criteria of histopathological evaluation and classification. Multiple tumors of different type and site, of different type in the same site, of the same type in bilateral organs, of the same type in the skin, in the subcutaneous tissue, and in mammary glands, or at distant sites of diffuse tissue (i.e., bones and skeletal muscle) were plotted as single/independent tumors. Multiple tumors of the same type in the same tissue and organ (including those of the bilateral organs) were plotted only once.

Statistical analysis was performed using the $\chi^{2}$ test to evaluate differences in tumor incidence between treated and control groups. The Cochrane Armitage test was used to evaluate dose-response relations.

\section{RESULTS}

\section{Methyl Alcohol}

There were no noteworthy changes in beverage or feed consumption apart from a decrease in water consumption in females treated with the highest dose between 8 
TABLE 3. Long-term carcinogenicity bioassays on methyl alcohol administered with drinking water supplied ad libitum to male (M) and female (F) Sprague-Dawley rats

\begin{tabular}{|c|c|c|c|c|c|c|c|c|c|c|c|c|c|c|c|c|c|c|}
\hline \multicolumn{19}{|c|}{ CARCINOMAS OF THE HEAD AND NECK } \\
\hline \multirow{3}{*}{$\begin{array}{l}\text { Group } \\
\text { No. }\end{array}$} & \multirow{3}{*}{$\begin{array}{c}\text { Concentration } \\
(\mathrm{ppm}, \mathrm{v} / \mathrm{v})\end{array}$} & \multirow{2}{*}{\multicolumn{2}{|c|}{ Animals }} & \multicolumn{15}{|c|}{ Animals with carcinomas } \\
\hline & & & & \multicolumn{2}{|c|}{$\begin{array}{l}\text { Zymbal } \\
\text { glands }\end{array}$} & \multicolumn{2}{|c|}{ Ear ducts ${ }^{\mathrm{a}}$} & \multicolumn{2}{|c|}{$\begin{array}{c}\text { Nasal } \\
\text { cavities }\end{array}$} & \multicolumn{2}{|c|}{$\begin{array}{l}\text { Oral cavity, } \\
\text { tongue and lips }\end{array}$} & \multicolumn{2}{|c|}{ Pharynx } & \multicolumn{2}{|c|}{ Larynx } & \multicolumn{3}{|c|}{ Total } \\
\hline & & Sex & No. & No. & $\%$ & No. & $\%$ & No. & $\%$ & No. & $\%$ & No. & $\%$ & No. & $\%$ & No. & $\%$ & \\
\hline \multirow[t]{3}{*}{ I } & 20,000 & M & 100 & 3 & 3.0 & $24(5)$ & $24.0^{-m+4}$ & 0 & - & 1 & 1.0 & 0 & - & 1 & 1.0 & 29 & $29.0^{*}$ & $m+\bullet$ \\
\hline & & $\mathrm{F}$ & 100 & 4 & 4.0 & $19(2)$ & $19.0^{\star 4}$ & 1 & 1.0 & 1 & 1.0 & 0 & . & 0 & - & 25 & 25.0 " & +4 \\
\hline & & $\mathrm{M}+\mathrm{F}$ & 200 & 7 & 3.5 & 43 & 21.5 & 1 & 0.5 & 2 & 1.0 & 0 & - & 1 & 0.5 & 54 & 27.0 & \\
\hline \multirow[t]{3}{*}{ II } & 5,000 & $\mathrm{M}$ & 100 & 2 & 2.0 & $17(3)$ & $17.0 \leftrightarrow$ & 0 & - & 2 & 2.0 & 1 & 1.0 & 0 & - & 22 & 22.0 & $\leftrightarrow$ \\
\hline & & $\mathrm{F}$ & 100 & 3 & 3.0 & $16(4)$ & $16.0^{\star}$ & 0 & - & 0 & - & 0 & - & 0 & - & 19 & 19.0 & 4 \\
\hline & & $\mathrm{M}+\mathrm{F}$ & 200 & 5 & 2.5 & 33 & 16.5 & 0 & - & 2 & 1.0 & 1 & 0.5 & 0 & - & 41 & 20.5 & \\
\hline \multirow[t]{3}{*}{ III } & 500 & M & 100 & 2 & 2.0 & $13(3)$ & $13.0^{+}$ & 1 & 1.0 & 0 & - & 0 & - & 0 & - & 16 & 16.0 & 4 \\
\hline & & $\mathrm{F}$ & 100 & 3 & 3.0 & $8(2)$ & 8.0 & 1 & 1.0 & 0 & . & 1 & 1.0 & 0 & - & 13 & 13.0 & $\leftrightarrow$ \\
\hline & & $\mathrm{M}+\mathrm{F}$ & 200 & 5 & 2.5 & 21 & 10.5 & 2 & 1.0 & 0 & - & 1 & 0.5 & 0 & - & 29 & 14.5 & \\
\hline \multirow[t]{3}{*}{ IV } & 0 & M & 100 & 1 & 1.0 & $9(1)$ & 9.0 & 1 & 1.0 & 1 & 1.0 & 0 & . & 0 & - & 12 & 12.0 & \\
\hline & & $\mathrm{F}$ & 100 & 1 & 1.0 & $9(1)$ & 9.0 & 0 & - & 3 & 3.0 & 0 & - & 0 & - & 13 & 13.0 & \\
\hline & & $M+F$ & 200 & 2 & 1.0 & 18 & 9.0 & 1 & 0.5 & 4 & 2.0 & 0 & - & 0 & - & 25 & 12.5 & \\
\hline
\end{tabular}

${ }^{a}$ Between brackets the number of animals with bilateral tumors

$\mathrm{p}<0.05$ using $\chi^{2}$ test

$\mathrm{p}<0.01$ using $\chi^{2}$ test

- $\mathrm{p}<0.05$ using Cochrane-Armitage test for dose-response relationship

* $\mathrm{p}<0.01$ using Cochrane-Armitage test for dose-response relationship 
TABLE 4. Long-term carcinogenicity bioassays on methyl alcohol administered with drinking water supplied ad libitum to male (M) and female (F) Sprague-Dawley rats

\begin{tabular}{|c|c|c|c|c|c|c|c|c|c|}
\hline \multicolumn{10}{|c|}{ OSTEOSARCOMAS OF THE HEAD AND OTHER SITES } \\
\hline \multirow{3}{*}{$\begin{array}{c}\text { Group } \\
\text { No. }\end{array}$} & \multirow{3}{*}{$\begin{array}{l}\text { Concentration } \\
(\mathrm{ppm}, \mathrm{v} / \mathrm{v})\end{array}$} & \multirow{2}{*}{\multicolumn{2}{|c|}{ Animals }} & \multicolumn{6}{|c|}{ Animals with osteosarcomas } \\
\hline & & & & \multicolumn{2}{|c|}{ Head } & \multicolumn{2}{|c|}{ Other sites } & \multicolumn{2}{|c|}{ Total } \\
\hline & & Sex & No. & $\overline{\text { No. }}$ & $\%$ & No. & $\%$ & No. & $\%$ \\
\hline \multirow[t]{3}{*}{$\mathrm{I}$} & 20,000 & $\mathrm{M}$ & 100 & 11 & 11.0 & 1 & 1.0 & 12 & 12.0 \\
\hline & & $\mathrm{F}$ & 100 & 6 & 6.0 & 0 & - & 6 & 6.0 \\
\hline & & $\mathrm{M}+\mathrm{F}$ & 200 & 17 & 8.5 & 1 & 0.5 & 18 & 9.0 \\
\hline \multirow[t]{3}{*}{ II } & 5,000 & M & 100 & 13 & 13.0 & 0 & - & 13 & 13.0 \\
\hline & & $\mathrm{F}$ & 100 & 3 & 3.0 & 0 & - & 3 & 3.0 \\
\hline & & $\mathrm{M}+\mathrm{F}$ & 200 & 16 & 8.0 & 0 & - & 16 & 8.0 \\
\hline \multirow[t]{3}{*}{ III } & 500 & M & 100 & 6 & 6.0 & 1 & 1.0 & 7 & 7.0 \\
\hline & & $\mathrm{F}$ & 100 & 4 & 4.0 & 1 & 1,0 & 5 & 5.0 \\
\hline & & $M+F$ & 200 & 10 & 5.0 & 2 & 1.0 & 12 & 6.0 \\
\hline \multirow[t]{3}{*}{ IV } & 0 & M & 100 & 6 & 6.0 & 2 & 2.0 & 8 & 8.0 \\
\hline & & $\mathrm{F}$ & 100 & 1 & 1.0 & 0 & - & 1 & 1.0 \\
\hline & & $\mathrm{M}+\mathrm{F}$ & 200 & 7 & 3.5 & 2 & 1,0 & 9 & 4.5 \\
\hline
\end{tabular}

and 56 weeks of age. A slight increase was observed in the body weight of males and, to a lesser extent, of females treated with the highest dose. No substantial changes in survival or behavioral changes were observed among the groups. No treatment-related nononcologic pathological changes were detected by gross inspection or histopathological examination.

The occurrence of benign and malignant tumors is shown in TABLE 1. Differences observed between treated and control animals were: (1) a dose-related increase of total malignant tumors in males and females of treated groups (TABLE 2); (2) a doserelated increase of carcinomas of the head and neck, mainly in the ear ducts, in males of treated groups and in females treated with 20,000 and 5,000 ppm (TABLE 3); (3) a statistically significant increase $(P<0.01)$ of testicular interstitial cell hyperplasias and adenomas in the group treated with the highest dose; (4) an increase in sarcomas of the uterus at the highest dose; (5) a dose-related increase in osteosarcomas of the head in males and females of the treated groups (TABLE 4); and (6) a dose-related increase in hemolymphoreticular neoplasias in males and females of the treated groups (TABLE 5).

\section{Ethyl Alcohol}

The intake of beverages and feed was lower in treated than control animals. No significant differences in body weight or behavior were observed between treated and control animals. No significant differences occurred in survival between treated and control animals, with the exception of a lower survival of treated female off- 
TABLE 5. Long-term carcinogenicity bioassays on methyl alcohol administered with drinking water supplied ad libitum to male (M) and female (F) Sprague-Dawley rats

\section{HEMOLYMPHORETICULAR NEOPLASIAS AND THEIR DISTRIBUTION BY HISTOCYTOTYPE}

\begin{tabular}{|c|c|c|c|c|c|c|c|c|c|c|c|c|c|c|c|c|}
\hline \multirow{3}{*}{$\begin{array}{l}\text { Group } \\
\text { No. }\end{array}$} & \multirow{3}{*}{$\begin{array}{l}\text { Concentration } \\
(\mathrm{ppm}, \mathrm{v} / \mathrm{v})\end{array}$} & \multirow{2}{*}{\multicolumn{2}{|c|}{ Animals }} & \multicolumn{13}{|c|}{ Animals with hemolymphoreticular neoplasias } \\
\hline & & & & \multicolumn{2}{|c|}{ Total $^{a}$} & \multicolumn{2}{|c|}{$\begin{array}{l}\text { Lymphoblastic } \\
\text { lymphoma }^{b}\end{array}$} & \multicolumn{2}{|c|}{$\begin{array}{c}\text { Lymphoblastic } \\
\text { leukemia } \\
\end{array}$} & \multicolumn{2}{|c|}{$\begin{array}{l}\text { Lymphocytic } \\
\text { lymphoma }^{b} \\
\end{array}$} & \multicolumn{2}{|c|}{$\begin{array}{l}\text { Lymphoimmuno- } \\
\text { blastic lymphoma }\end{array}$} & \multicolumn{2}{|c|}{$\begin{array}{l}\text { Histiocytic sarcoma } \\
\text { monocytic leukemia }^{b}\end{array}$} & $\begin{array}{r}\text { Myeloid } \\
\text { leukemia } \\
\end{array}$ \\
\hline & & Sex & No. & No. & $\%$ & No. & $\%$ & No, & $\%$ & No. & $\%$ & No. & $\%$ & No. & $\%$ & No. $\%$ \\
\hline \multirow[t]{3}{*}{ I } & 20,000 & $\mathrm{M}$ & 100 & 40 & 40.0 & 1 & 2.5 & 0 & - & 0 & - & 37 & 92.5 & 1 & 2.5 & 12.5 \\
\hline & & $\mathrm{F}$ & 100 & 28 & $28.0^{m+}$ & 1 & 3.6 & 0 & - & 0 & . & 21 & 75.0 & 3 & 10.7 & $\begin{array}{ll}310.7 \\
\end{array}$ \\
\hline & & $\mathrm{M}+\mathrm{F}$ & 200 & 68 & 34.0 & 2 & 2.9 & 0 & - & 0 & - & 58 & 85.3 & 4 & 5.9 & $4 \quad 5.9$ \\
\hline \multirow[t]{3}{*}{ II } & 5,000 & $\mathrm{M}$ & 100 & 36 & 36.0 & 1 & 2.8 & 0 & - & 0 & - & 28 & 77.8 & 1 & 2.8 & $\begin{array}{ll}6 & 16.7\end{array}$ \\
\hline & & $\mathrm{F}$ & 100 & $24^{\mathfrak{E}}$ & 24.0 & 1 & 4.2 & 0 & - & 0 & - & 19 & 79.2 & 2 & 8.3 & 312.5 \\
\hline & & $\mathrm{M}+\mathrm{F}$ & 200 & $60^{\mathrm{c}}$ & 30.0 & 2 & 3.3 & 0 & - & 0 & - & 47 & 78.3 & 3 & 5.0 & 915.0 \\
\hline \multirow[t]{3}{*}{ III } & 500 & $\mathrm{M}$ & 100 & 35 & 35.0 & 3 & 8.6 & 0 & - & 0 & - & 24 & 68.6 & 4 & 11.4 & 411.4 \\
\hline & & $\mathrm{F}$ & 100 & 24 & $24.0^{\circ}$ & 1 & 4.2 & 0 & . & 1 & 4.2 & 17 & 70.8 & 2 & 8.3 & 312.5 \\
\hline & & $\mathrm{M}+\mathrm{F}$ & 200 & 59 & 29.5 & 4 & 6.8 & 0 & - & 1 & 1.7 & 41 & 69.5 & 6 & 10.2 & 711.9 \\
\hline \multirow[t]{3}{*}{ IV } & 0 & $\mathrm{M}$ & 100 & 28 & 28.0 & 1 & 3.6 & 0 & - & 0 & - & 16 & 57.1 & 3 & 10.7 & 828.6 \\
\hline & & $\mathrm{F}$ & 100 & 13 & 13.0 & 0 & - & 0 & - & 0 & . & 9 & 69.2 & 1 & 7.7 & 323.1 \\
\hline & & $\mathrm{M}+\mathrm{F}$ & 200 & 41 & 20.5 & 1 & 2.4 & 0 & - & 0 & - & 25 & 61.0 & 4 & 9.8 & 1126.8 \\
\hline
\end{tabular}

a Percentages refer to the number of animals at start

${ }^{b}$ Percentages refer to the number of animals bearing hemolymphoreticular neoplasias

c One animal bore a lymphoimmunoblastic lymphoma and myeloid leukemia

* $\mathrm{p}<0,05$ using $\chi^{2}$ test

- $p<0.05$ using Cochrane-Armitage test for dose-response relationship 
TABLE 6. Long-term carcinogenicity bioassays on ethyl alcohol administered with drinking water supplied ad libitum to male (M) and female (F) Sprague-Dawley rats

\begin{tabular}{|c|c|c|c|c|c|c|c|c|c|c|c|c|c|c|c|c|}
\hline \multirow{4}{*}{ Site } & \multicolumn{16}{|c|}{ Groups } \\
\hline & \multicolumn{4}{|c|}{$\begin{array}{c}\text { I. Ethyl alcohol } 10 \% \\
\text { (Breeders) }\end{array}$} & \multicolumn{4}{|c|}{$\begin{array}{l}\text { I1: Drinking water } \\
\text { (Breeders) }\end{array}$} & \multicolumn{4}{|c|}{$\begin{array}{l}\text { III: Ethyl alcohol 10\% } \\
\text { (Offspring) }\end{array}$} & \multicolumn{4}{|c|}{$\begin{array}{l}\text { IV: Drinking water } \\
\text { (Offspring) }\end{array}$} \\
\hline & \multicolumn{2}{|c|}{ Male } & \multicolumn{2}{|c|}{ Female } & \multicolumn{2}{|c|}{ Male } & \multicolumn{2}{|c|}{ Female } & \multicolumn{2}{|c|}{ Male } & \multicolumn{2}{|c|}{ Female } & \multicolumn{2}{|c|}{ Male } & \multicolumn{2}{|c|}{ Female } \\
\hline & No. & $\%$ & No. & $\%$ & No. & $\%$ & Ao. & $\%$ & No. & $\%$ & No. & $\%$ & No. & $\%$ & No. & $\%$ \\
\hline $\begin{array}{l}\text { Bones } \\
\text { - Head }\end{array}$ & & & & & & & & & & & & & & & & \\
\hline $\begin{array}{l}\text { Osteosarcoma } \\
\text { - Other sites }\end{array}$ & 8 & 7.3 & 6 & 5.5 & 0 & - & 4 & 3.6 & 6 & 20.0 & 4 & 10.3 & 4 & 8.2 & 3 & 5.5 \\
\hline Osteosarcoma & 4 & 36 & 0 & - & 1 & 0.9 & 0 & - & 0 & - & 1 & 2.6 & 0 & - & 0 & - \\
\hline Chondrosarcoma & 0 & - & 0 & . & 0 & . & 0 & . & 1 & 3.3 & 0 & - & 0 & - & 0 & - \\
\hline Soft tissues & & & & & & & & & & & & & & & & \\
\hline Liposarcoma & 0 & - & 0 & - & 0 & - & 0 & - & 1 & 3.3 & 0 & - & 0 & - & 0 & - \\
\hline Heart & & & & & & & & & & & & & & & & \\
\hline $\begin{array}{l}\text { Malignant Schwannoma } \\
\text { Thymus }\end{array}$ & 0 & - & 2 & 1.8 & 1 & 0.9 & 1 & 0.9 & 0 & - & 0 & - & 0 & - & 0 & - \\
\hline $\begin{array}{l}\text { Malignant thymoma }{ }^{\mathrm{c}} \\
\text { Spleen }\end{array}$ & 0 & . & 0 & - & 0 & - & 1 & 0.9 & 0 & - & 0 & - & 0 & - & 0 & - \\
\hline Fibroma & 0 & - & 0 & . & 1 & 0.9 & 0 & - & 0 & . & 0 & - & 0 & - & 0 & - \\
\hline Fibroangioma & 2 & 1.8 & 0 & - & 1 & 0.9 & 0 & - & 0 & - & 1 & 2.6 & 1 & 2.0 & 0 & - \\
\hline $\begin{array}{l}\text { Mesenteric lymph nodes } \\
\text { Fibroangioma }\end{array}$ & 1 & 0.9 & 0 & - & 1 & 0.9 & 0 & - & 2 & 6.7 & 1 & 2.6 & 1 & 2.0 & 1 & 1.8 \\
\hline $\begin{array}{l}\text { Hemolvmphoreticulas tissue }{ }^{\mathrm{d}} \\
\text { Lymphomas and letkemias }\end{array}$ & 39 & 35.5 & 46 & 41.8 & 35 & 31.8 & 17 & 15.5 & 9 & 30.0 & 8 & 20.5 & $8(10)$ & 20.4 & 11 & 20.0 \\
\hline
\end{tabular}

Between brackets the number of tumors (one animal can bear more than one tumor)

See table 8

E In $96 \%$ of cases the tumor itself is composed of a mixture in varying proportions of epithelial cells and lymphocytes. In the remaining $4 \%$, only epithelial cells are present. We consider that a tumor

composed exclusively of lymphocytes should not be classified as a thymoma but as a lymphoma involving the thymus.

composed exclusively of lymphocytes should not be clas
including thymus, spleen and mesenteric lymph nodes 


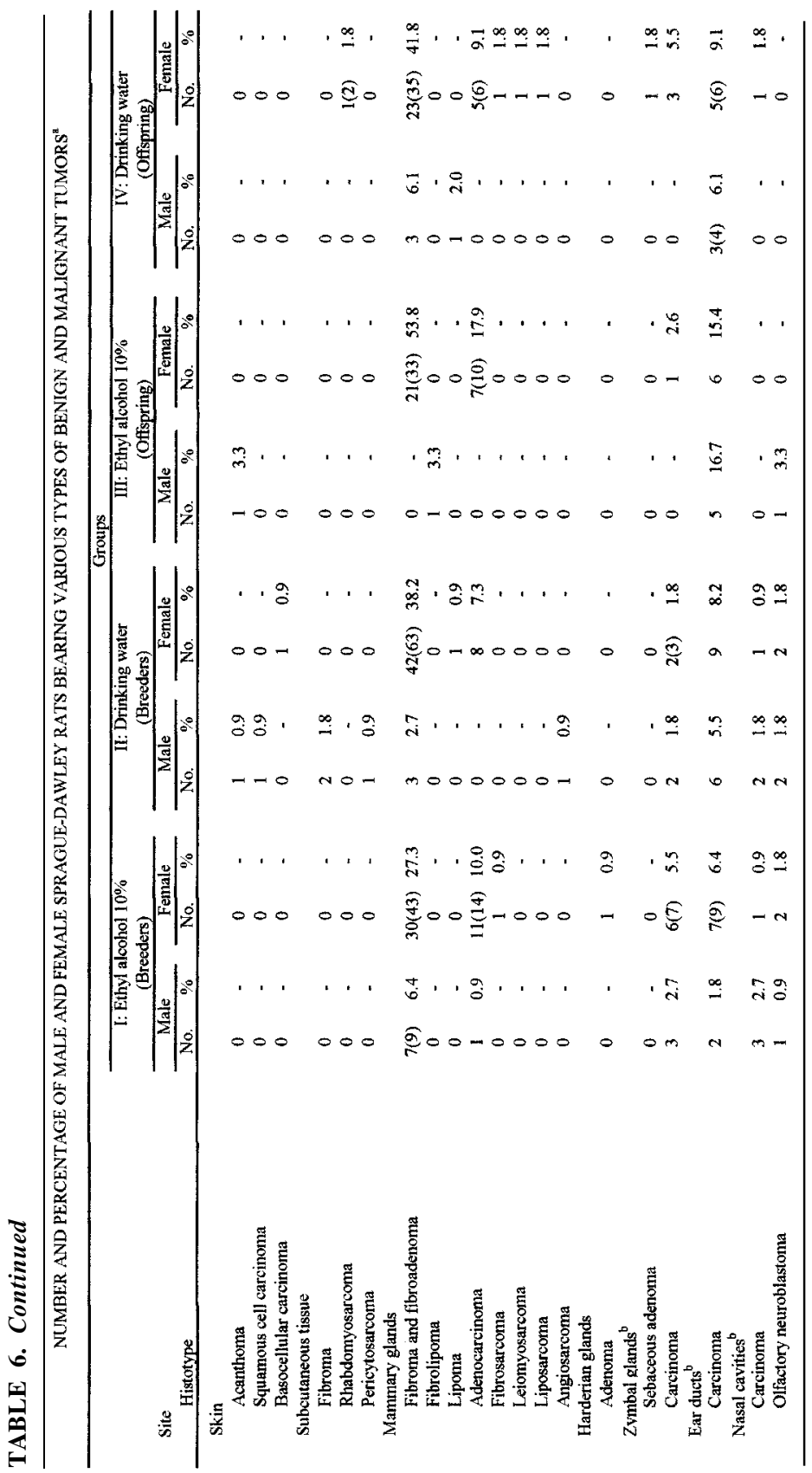




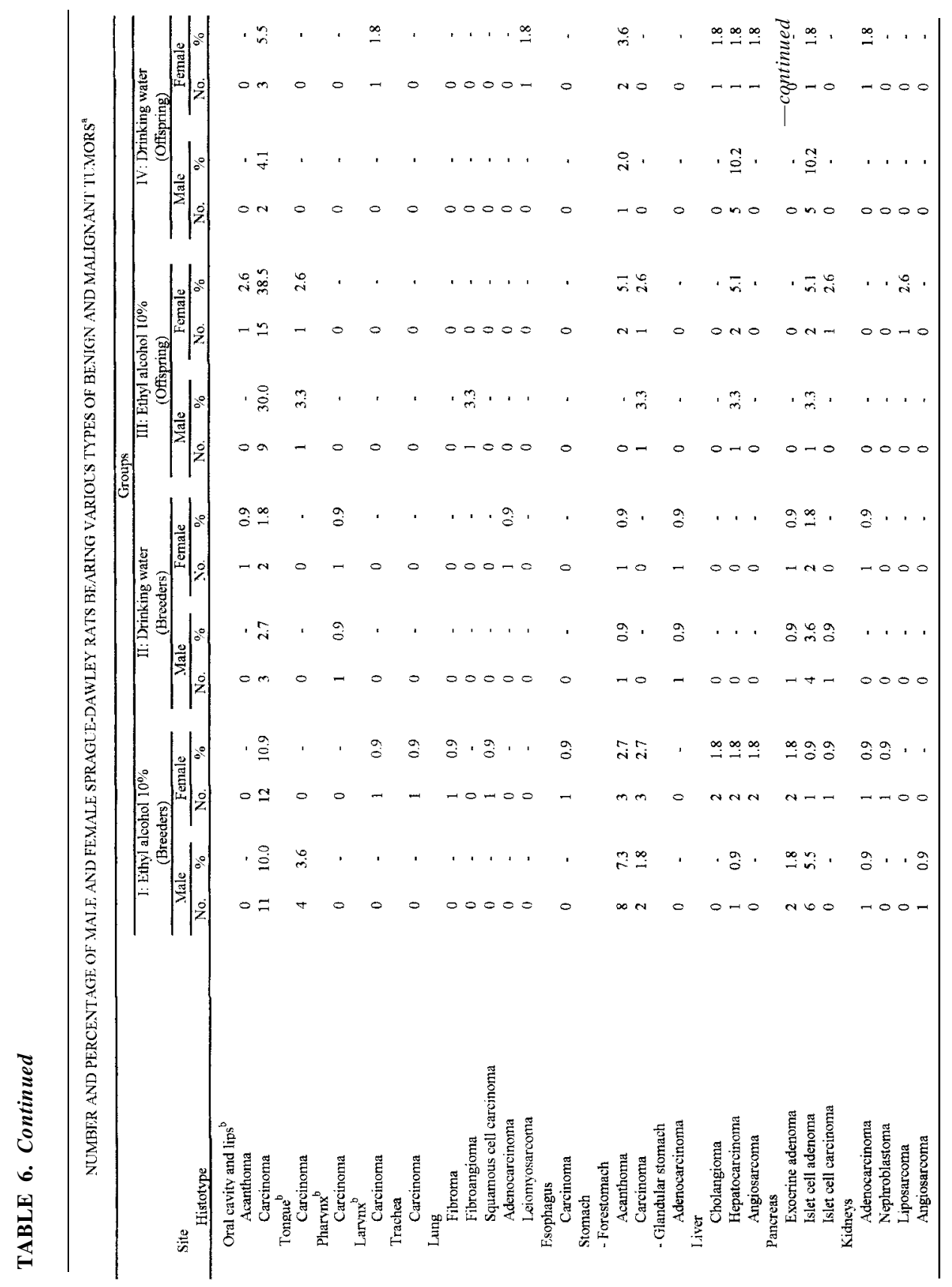




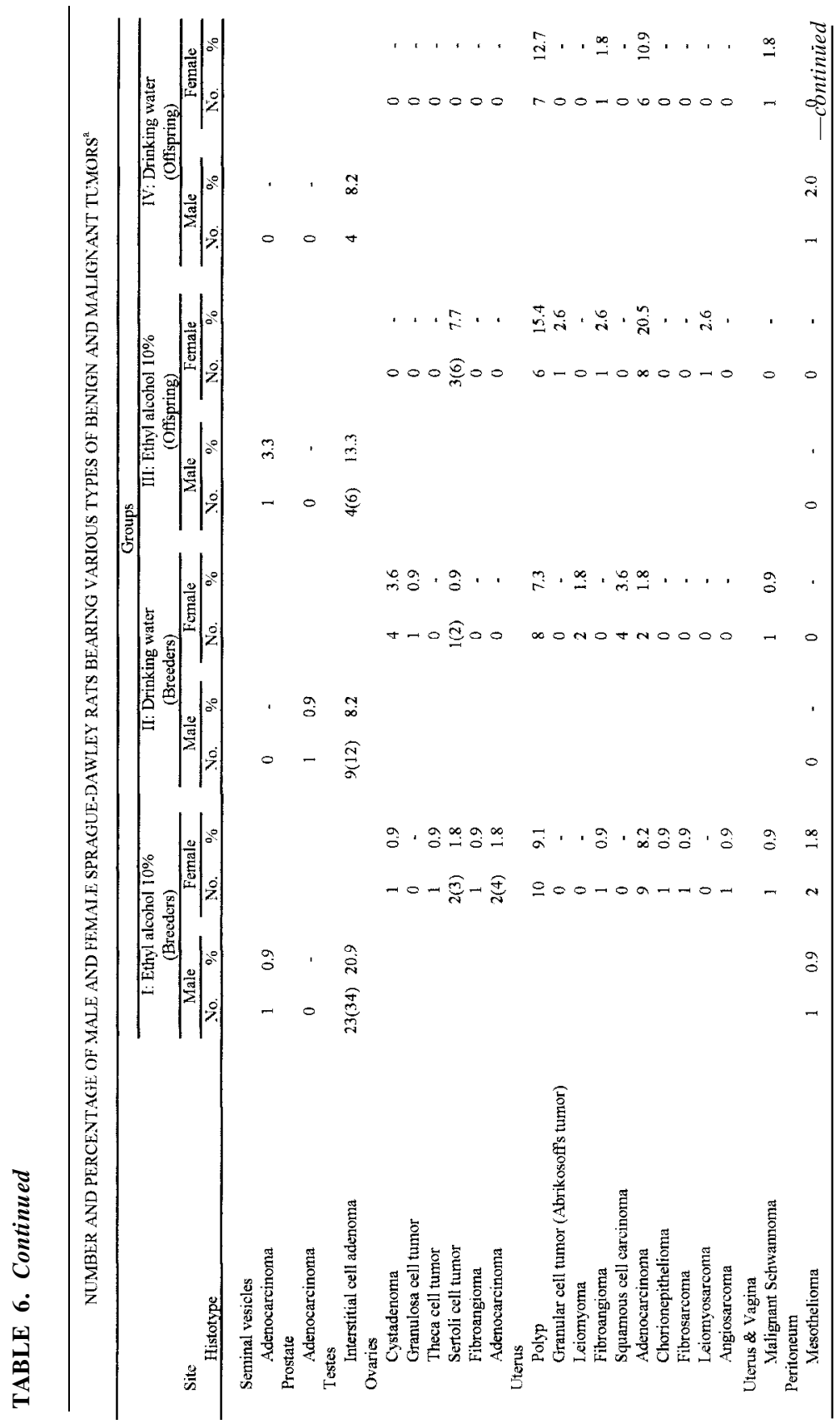


TO'TAL MALIGNANT TUMORS

\begin{tabular}{|c|c|c|c|c|c|c|c|}
\hline \multirow{3}{*}{$\begin{array}{l}\text { Group } \\
\text { No. }\end{array}$} & \multirow{3}{*}{$\begin{array}{c}\text { Concentration } \\
(\mathrm{ppm}, \mathrm{v} / \mathrm{v})\end{array}$} & \multirow{2}{*}{\multicolumn{2}{|c|}{ Animals }} & \multicolumn{4}{|c|}{ Malignant tumors } \\
\hline & & & & \multicolumn{2}{|c|}{ Tumor-bearing animals } & \multicolumn{2}{|c|}{ Tumors } \\
\hline & & Sex & No. & No. & $\%$ & No. & Per 100 animals \\
\hline \multirow[t]{3}{*}{ I } & 20,000 & $\mathrm{M}$ & 100 & 70 & $70.0^{m+\cdots}$ & 104 & $104.0^{-m}$ \\
\hline & & $\mathrm{F}$ & 100 & 63 & $63.0^{n+4+4}$ & 95 & 95.0 \\
\hline & & $\mathrm{M}+\mathrm{F}$ & 200 & 133 & 66.5 & 199 & 99.5 \\
\hline \multirow[t]{3}{*}{ II } & 5,000 & $\mathrm{M}$ & 100 & 64 & $64.0 " 4$ & 97 & $97.0^{+\cdots}$ \\
\hline & & $\mathrm{F}$ & 100 & 48 & $48.0^{\text {*t }}$ & 73 & 73.0 \\
\hline & & $\mathrm{M}+\mathrm{F}$ & 200 & 112 & 56.0 & 170 & 85.0 \\
\hline \multirow[t]{3}{*}{ III } & 500 & $\mathrm{M}$ & 100 & 55 & $55.0^{* 4}$ & 78 & 78.0 \\
\hline & & $\mathrm{F}$ & 100 & 48 & $48.0^{*+}$ & 72 & 72.0 \\
\hline & & $\mathrm{M}+\mathrm{F}$ & 200 & 103 & 51.5 & 150 & 75.0 \\
\hline \multirow[t]{3}{*}{ IV } & 0 & M & 100 & 50 & 50.0 & 66 & 66.0 \\
\hline & & $\mathrm{F}$ & 100 & 43 & 43.0 & 60 & 60.0 \\
\hline & & $M+F$ & 200 & 93 & 46.5 & 126 & 63.0 \\
\hline
\end{tabular}

p $<0.01$ using $\chi^{2}$ test

* $p<0.01$ using Cochrane-Armitage test for dose-response relationship 
TABLE 7. Long-term carcinogenicity bioassays on ethyl alcohol administered with drinking water supplied ad libitum to male (M) and female (F) Sprague-Dawley rats

TOTAL MALIGNANT TUMORS

\begin{tabular}{|c|c|c|c|c|c|c|c|c|}
\hline \multirow{3}{*}{$\begin{array}{c}\text { Group } \\
\text { No. }\end{array}$} & \multirow{3}{*}{$\begin{array}{c}\text { Concentration } \\
(\%, v / v)\end{array}$} & \multirow{2}{*}{\multicolumn{3}{|c|}{ Animals }} & \multicolumn{4}{|c|}{ Malignant tumors } \\
\hline & & & & & \multicolumn{2}{|c|}{ Tumor-bearing animals } & \multicolumn{2}{|c|}{ Tumors } \\
\hline & & Age & Sex & No. & No. & $\%$ & No. & Per 100 animals \\
\hline \multirow[t]{3}{*}{ I } & \multirow[t]{3}{*}{10} & \multirow{3}{*}{$\begin{array}{l}39 \text { weeks } \\
\text { (breeders) }\end{array}$} & $\mathrm{M}$ & 110 & 66 & 60.0 & 98 & $89.1^{m+\infty}$ \\
\hline & & & $\mathrm{F}$ & 110 & 79 & 71.8 & 143 & $130.0^{*+4}$ \\
\hline & & & $\mathrm{M}+\mathrm{F}$ & 220 & 145 & 65.9 & 241 & 109.5 \\
\hline \multirow[t]{3}{*}{ II } & \multirow[t]{3}{*}{0} & \multirow{3}{*}{$\begin{array}{l}39 \text { weeks } \\
\text { (breeders) }\end{array}$} & $\mathbf{M}$ & 110 & 51 & 46.4 & 68 & 61.8 \\
\hline & & & $\mathrm{F}$ & 110 & 48 & 43.6 & 67 & 60.9 \\
\hline & & & $\mathrm{M}+\mathrm{F}$ & 220 & 99 & 45.0 & 135 & 61.4 \\
\hline \multirow[t]{3}{*}{ III } & \multirow[t]{3}{*}{10} & \multirow{3}{*}{$\begin{array}{l}\text { Embryos } \\
\text { (offspring) }\end{array}$} & M & 30 & 23 & $76.7^{*}$ & 41 & $136.7^{+0+4}$ \\
\hline & & & $\mathrm{F}$ & 39 & 26 & 66.7 & 64 & $164.1^{-}$ \\
\hline & & & $\mathrm{M}+\mathrm{F}$ & 69 & 49 & 71.0 & 105 & 152.2 \\
\hline \multirow[t]{3}{*}{ IV } & \multirow[t]{3}{*}{0} & \multirow{3}{*}{$\begin{array}{l}\text { Embryos } \\
\text { (offspring) }\end{array}$} & M & 49 & 23 & 46.9 & 30 & 61.2 \\
\hline & & & $\mathrm{F}$ & 55 & 31 & 56.4 & 53 & 96.4 \\
\hline & & & $\mathrm{M}+\mathrm{F}$ & 104 & 54 & 51.9 & 83 & 79.8 \\
\hline
\end{tabular}

${ }^{*} \mathrm{p}<0.05$ using $\chi^{2}$ test

$\cdots 0.01$ using $\chi^{2}$ test 
TABLE 8. Long-term carcinogenicity bioassays on ethyl alcohol administered with drinking water supplied ad libitum to male (M) and female (F) Sprague-Dawley rats

CARCINOMAS OF THE HEAD AND NECK

\begin{tabular}{|c|c|c|c|c|c|c|c|c|c|c|c|c|c|c|c|c|c|c|}
\hline \multirow{3}{*}{$\begin{array}{l}\text { Group } \\
\text { No. }\end{array}$} & \multirow{3}{*}{$\begin{array}{c}\text { Concentration } \\
(\%, v / v)\end{array}$} & \multirow{2}{*}{\multicolumn{3}{|c|}{ Animals }} & \multicolumn{14}{|c|}{ Animals with carcinomas } \\
\hline & & & & & \multicolumn{2}{|c|}{$\begin{array}{l}\text { Zymbal } \\
\text { glands }\end{array}$} & \multicolumn{2}{|c|}{ Ear ducts ${ }^{\mathrm{a}}$} & \multicolumn{2}{|c|}{$\begin{array}{c}\text { Nasal } \\
\text { cavities }\end{array}$} & \multicolumn{2}{|c|}{$\begin{array}{l}\text { Oral cavity, } \\
\text { tongue and lips }\end{array}$} & \multicolumn{2}{|c|}{ Pharynx } & \multicolumn{2}{|c|}{ Larynx } & \multicolumn{2}{|c|}{ Total } \\
\hline & & Age & Sex & No. & No. & $\%$ & No. & $\%$ & No. & $\%$ & No. & $\%$ & No. & $\%$ & No. & $\%$ & No. & $\%$ \\
\hline \multirow[t]{3}{*}{ I } & 10 & 39 weeks & M & 110 & 3 & 2.7 & 2 & 1.8 & 3 & 2.7 & 15 & $13.6^{\text {*o* }}$ & 0 & - & 0 & - & 23 & 20.9 \\
\hline & & (breeders) & $\mathrm{F}$ & 110 & $6(1)$ & 5.5 & $7(2)$ & 6.4 & 1 & 0.9 & 12 & $10.9^{*}$ & 0 & - & 1 & 0.9 & 27 & 24.5 \\
\hline & & & $\mathrm{M}+\mathrm{F}$ & 220 & 9 & 4.1 & 9 & 4.1 & 4 & 1.8 & 27 & 12.3 & 0 & - & 1 & 0.5 & 50 & 22.7 \\
\hline \multirow[t]{3}{*}{ II } & 0 & 39 weeks & $\mathrm{M}$ & 110 & 2 & 1.8 & 6 & 5.5 & 2 & 1.8 & 3 & 2.7 & 1 & 0.9 & 0 & - & 14 & 12.7 \\
\hline & & (breeders) & $F$ & 110 & $2(1)$ & 1.8 & 9 & 8.2 & 1 & 0.9 & 2 & 1.8 & 1 & 0.9 & 0 & - & 15 & 13.6 \\
\hline & & & $\mathbf{M}+\mathbf{F}$ & 220 & 4 & 1.8 & 15 & 6.8 & 3 & 1.4 & 5 & 2.3 & 2 & 0.9 & 0 & - & 29 & 13.2 \\
\hline \multirow[t]{3}{*}{ III } & 10 & Embryos & $\mathrm{M}$ & 30 & 0 & - & 5 & 16.7 & 0 & - & 10 & $33.3^{* *}$ & 0 & - & 0 & - & 15 & $50.0^{m+m}$ \\
\hline & & (offspring) & $\mathrm{F}$ & 39 & 1 & 2.6 & 6 & 15.4 & 0 & - & 16 & $41.0^{* *}$ & 0 & - & 0 & - & 23 & $59.0^{* * *}$ \\
\hline & & & $\mathrm{M}+\mathrm{F}$ & 69 & 1 & 1.4 & 11 & 15.9 & 0 & - & 26 & 37.7 & 0 & - & 0 & - & 38 & 55.1 \\
\hline \multirow[t]{3}{*}{ IV } & 0 & Embryos & $\mathrm{M}$ & 49 & 0 & - & $3(1)$ & 6.1 & 0 & - & 2 & 4.1 & 0 & - & 0 & - & 5 & 10.2 \\
\hline & & (offspring) & $\mathrm{F}$ & 55 & 3 & 5.5 & $5(1)$ & 9.1 & 1 & 1.8 & 3 & 5.5 & 0 & - & 1 & 1.8 & 13 & 23.6 \\
\hline & & & $\mathbf{M}+\mathbf{F}$ & 104 & 3 & 2.9 & 8 & 7.7 & 1 & 1.0 & 5 & 4.8 & 0 & - & 1 & 1.0 & 18 & 17.3 \\
\hline
\end{tabular}

Between brackets the number of animals with bilateral tumors

* $p<0.05$ using $\chi^{2}$ test

** $\mathrm{p}<0.01$ using $\chi^{2}$ test 
spring in the period from 104 to 152 weeks of age. No treatment-related nononcological pathological changes were detected by gross inspection or histopathological examination.

The occurrence of benign and malignant tumors is shown in TABLE 6. Differences observed between treated and control animals were: (1) an increase in total malignant tumors in males and females, breeders, and offspring (TABLE 7); (2) an increase in total malignant mammary tumors per 100 animals in females, breeders, and offspring; (3) an increase in head and neck carcinomas, especially of the oral cavity, lips, and tongue, in males and females, breeders, and offspring (TABLE 8); (4) an increase in squamous cell carcinomas of the forestomach in males and females, breeders, and offspring; (5) an increase in interstitial cell adenomas of the testis in male breeders $(P<0.05)$ and offspring; $(6)$ an increase in Sertoli cell tumors (ovary) in female offspring; (7) an increase in adenocarcinomas of the uterus in breeders and offspring; (8) an increase in pheochromoblastoma in male and female breeders and male offspring; and (9) an increase in osteosarcomas of the head and other sites in male breeders $(P<0.01)$ and offspring and in female breeders and offspring.

\section{CONCLUSIONS}

Methyl alcohol and ethyl alcohol were found to be carcinogenic for various tissues and organs. Based on these findings, methyl alcohol and ethyl alcohol must be considered multipotential carcinogenic agents.

Whether and to what extent methyl alcohol and ethyl alcohol exert their carcinogenic effects directly or through their metabolic products, formaldehyde and acetaldehyde, respectively, or by enhancing the effects of endogenous and exogenous carcinogenic factors are not known. Based on our data, the use and diffusion of methyl alcohol and ethyl alcohol must take into account these pathological effects for the protection of public health.

It is noteworthy that in the tested experimental conditions, ethyl alcohol was shown, for the first time, to be carcinogenic to the oral cavity, tongue, and lips. These sites have been shown to be target organs in man by epidemiologic studies.

\section{ACKNOWLEDGMENTS}

This research was partially supported by the Regional Agency for Prevention and Environment (Agenzia Regionale Prevenzione e Ambiente, ARPA) of the EmiliaRomagna Region, Italy.

\section{REFERENCES}

1. Maltoni, C., A. Ciliberti, C. Pinto, et al. 1997. Results of long-term experimental carcinogenicity studies of the effects of gasoline, correlated fuels, and major gasoline aromatics on rats. Ann. N.Y. Acad. Sci. 837: 15-52.

2. Maltoni, C., A. Ciliberti, G. CotTi, et al. 1989. Benzene, an experimental multipotential carcinogen: results of the long-term bioassays performed at the Bologna Institute of Oncology. Environ. Health Perspect. 82: 109-124. 
3. Belpoggi, F., M. Soffritti \& C. Maltoni. 1995. Methyl-tertiary-butyl ether (MTBE), a gasoline additive, causes testicular and lymphohaematopoietic cancers in rats. Toxicol. Ind. Health. 11: 119-149.

4. Maltoni, C., F. Belpoggi, M. Soffritti, et al. 1999. Comprehensive long-term experimental project of carcinogenicity bioassays on gasoline oxygenated additives: plan and first report of results from the study on ethyl-tertiary butyl ether (ETBE). Eur. J. Oncol. 4: 493-508.

5. Soffritti, M., C. Maltoni, F. Maffei, et al. 1989. Formaldehyde: an experimental multipotential carcinogen. Toxicol. Ind. Health. 5: 699-730.

6. International Programme on Chemical Safety (IPCS). 1997. Methanol. Environmental Health Criteria 196. WHO. Geneva.

7. Grayson, M. 1981. Kirk-Othmer Encyclopedia of Chemical Technology, $3^{\text {rd }}$ edit. 15: 398-405. John Wiley \& Sons. New York.

8. Elvers, B., S. Hawkins \& G. Schulz. 1990. Ullmann's Encyclopedia of Industrial Chemistry, 5th edit. 16A: 465-486. VCH-Verlag.

9. SRI. 1992. Chemical Economics Handbook: Marketing Research Report on Methanol. SRI International. Menlo Park, CA.

10. CONCAWE. 1995. Alternative fuels in the automotive market. Brussels, CONCAWE, 67 pp (Report No. 2/95, prepared for the Concawe Automotive Emission Management Group by its Technical Coordinator, R.C. Hutcheson).

11. Fiedler, E., G. Grossmann, B. Kersebohm, et al. 1990. Methanol. In Ullmann's Encyclopedia of Industrial Chemistry, 5th edit. B. Weinheim, S. Elvers, G. Hawkins \& G. Schutz, Eds.: 16A: 465-486. VCH Verlag. Weinheim, Germany.

12. Axelrod, J. \& J. Daly. 1965. Pituitary gland: enzymic formation of methanol from Sadenosylmetionine. Science 158: 892-893.

13. CEC (Commission of the European Communities). 1988. Solvent in common use: Health risks to workers. Royal Society of Chemistry. Cambridge. Publication EUR/ 11553. 1-7, 157-186.

14. LeAF, G. \& L.J. Zatman. 1952. A study of the conditions under which methanol may exert a toxic hazard in industry. Br. J. Ind. Med. 9: 19-31.

15. Eriksen, S.P. \& A.B. KUlKarni. 1963. Methanol in normal human breath. Science 141: 639-640.

16. LARSSON, B.T. 1965. Gas chromatography of organic volatiles in human breath and saliva. Acta Med. Scand. 19: 159-164.

17. Krotoszynski, B.K., G.M. Bruneau \& H.J. O’Neill. 1979. Measurement of chemical inhalation exposure in urban populations in the presence of endogenous effluents. J. Anal. Toxicol. 3: 225-234.

18. Jones, A.W., S. Skagerberg, T. Yonekurat \& A. Sato. 1990. Metabolic interaction between endogenous ethanol studied in human volunteers by analysis of breath. Pharmacol. Toxicol. 66: 62-65.

19. Pellizzari, E.D, T.D. Hartwell, B.S.H. Harris III, et al. 1982. Purgeable organic compounds in mother's milk. Bull. Environ. Contam. Toxicol. 28: 322-328.

20. Kavet, R. \& K.M. Nauss. 1990. The toxicity of inhaled methanol vapors. CRC Crit. Rev. Toxicol. 21: 21-50.

21. Owens, L.D., R.G. Gilbert, G.E. Griebel \& J.D. Menzies. 1969. Identification of plant volatiles that stimulates microbial respiration and growth in soil. Phytopathology 59:1468-1472.

22. Holzer, G., H. Shanfield, A. Zlatkis, et al. 1977. Collection and analysis of trace emissions from natural sources. J. Chromatogr. 142: 755-764.

23. Graedel, T.E., D.T Hawkins \& L.D. Claxton. 1986. Atmospheric Chemical Compounds: Sources, Occurrence and Bioassay. 557: 512-514. Academic Press. New York. London.

24. U.S. EPA. 1994. 1992 Toxic release inventory: Public data. US Environmental Protection Agency (EPA 745/R-94-001). Washington, DC.

25. Medinsky, M.A. \& D.C Dorman. 1994. Assessing risks of low-level methanol exposure. CIIT Act. 14: 1-7. 
26. Gold, M.D. \& C.E. MouliF. 1988. Effects of emission standards on methanol vehiclerelated ozone, formaldehyde and methanol exposure. Presented at the 81 st Meeting of Air Pollution Control Association, Dallas, TX, June 19-24. Pittsburgh, PA.

27. U.S. EPA. 1976. Frequency of organic compounds identified in water. Washington, DC, US Environmental Protection Agency (EPA 600/4-76-062).

28. Kirchner, J.G. \& J.M. Miller. 1957. Volatile water-soluble and oil constituents of Valencia orange juice. J. Agric. Food Chem. 5: 283-291.

29. Francot, P. \& P. Geoffroy. 1956. Le méthanol dans les jus de fruits, les boissons fermentées des alcools et spiriteux. Rev. Ferment. Ind. Aliment. 11: 279-287.

30. Monte, W.C. 1984. Aspartame: methanol and the public health. J. Appl. Nutr. 36: 4254.

31. Greizerstein, H.B. 1981. Congener contents of alcoholic beverages. J. Stud. Alcohol 42: $1030-1037$.

32. Gilger, A.P. \& A.M. Potts. 1955. Studies on the visual toxicity of methanol. V. The role of acidosis in experimental methanol poisoning. Am. J. Ophthalmol. 39: 63-86.

33. New Energy Development Organization (NEDO). 1987. Toxicological research of methanol as a fuel for power station: summary report on test with monkeys, rats and mice. Tokyo: 1-296.

34. Katoh, M. 1989. New Energy Development Organization data. Presented at the Methanol Vapors and Health Effects Workshop: What we know and what we need to know - Summary Report. Washington, DC, ILSI Risk Science Institute/US Environmental Protection Agency/Health Effects Institute/American Petroleum Institute, A-7.

35. Mellan, I. 1950. Industrial Solvents: 454. Reinhold. New York.

36. Walsh, B. \& M. Grant. 1985. Public Health Implications of Alcohol Production and Trade (WHO Offset Publication No. 88). World Health Organization. Geneva.

37. BERG, C. 2001. World Ethanol Production 2001. http://www.distill.com/world_ ethanol_production.htm.

38. Mellan, I. 1950. Industrial Solvents: 460-466. Reinhold. New York.

39. Armstrong, S.R. 1999. Ethanol, Brief Report on its Use in Gasoline. Cambridge Environmental, Inc. Cambridge, MA.

40. Grosjean, E., D. Grosjean, R. Gunawardena \& R.A. Rasmussen. 1998. Environ. Sci. Technol. 32: 736.

41. Malcolm Pirnie, Inc. 1998. Evaluation of the Fate and Transport of Ethanol in the Environment. Prepared for the American Methanol Institute.

42. National Science and Technology Council (NSTC). 1997. Interagency Assessment of Oxygenate Fuels. Executive Office of the President.

43. Pohorecky, L.A. \& J. BRICK. 1988. Pharmacology of ethanol. Pharmacol. Ther. 36: $335-427$.

44. Ritchie, J.M. 1980. The aliphatic alcohols. In The Pharmacological Basis of Therapeutics. 6th edit.: 376-390. Macmillan. New York.

45. Holford, N.H.G. 1987. Clinical pharmacokinetics of ethanol. Clin. Pharmacokinet. 13: 273-292.

46. International Agency for Research on CAnCER. 1988. Monographs on the Evaluation of Carcinogenic Risks to Humans. Vol. 44. IARC, Lyon, France. 